\title{
Comparison of direct and indirect fluorescent antibody methods for staining Treponema pallidum
}

\author{
F. J. ELSAS \\ Venereal Disease Research Laboratory, Venereal Disease Branch, State and Community Services Division, \\ Center for Disease Control, Health Services and Mental Health Administration, Public Health Service, \\ U.S. Department of Health, Education and Welfare, Atlanta, Georgia 30333, U.S.A.
}

Both direct and indirect fluorescent antibody methods have been used to examine body fluids for the presence of Treponema pallidum. In the direct method (Yobs, Brown, and Hunter, 1964), fluorescein isothiocyanate (FITC)-labelled anti- $T$. pallidum globulin is layered directly upon the specimen suspected of containing treponemes. The indirect method is a double-layer procedure in which the specimen to be examined is first coated with syphilitic serum containing unlabelled anti-T. pallidum globulin, and this, in turn, is layered with FITC-labelled globulin directed against the species from which the serum was derived (Edwards, 1962). We have encountered no studies in which data comparing the two methods were presented. Because some investigators have expressed a preference for one method or the other (Israel, 1969; Wells and Smith, 1967; Rice, Dunlop, Jones, Hare, King, Rodin, Mushin, and Wilkinson, 1970), we wished to compare both methods concurrently, under similar conditions, to determine whether, with current reagents, one offered significant advantages. This information might be helpful in deciding upon a standard method to be used by all investigators searching for spiral organisms in body fluids.

\section{Material and methods}

ANTIGEN SLIDES

T. pallidum, Nichols strain, used as antigen for the fluorescent treponemal antibody-absorption test (FTAABS), was prepared by re-suspending the lyophilized organisms in sterile distilled water (U.S. Department of Health, Education, and Welfare, 1969). Reiter treponemes were taken from 8-day cultures. Those organisms designated as 'washed' were washed three times in saline and packed by centrifugation in an attempt to remove rabbit protein adsorbed to their surface. Fresh pathogenic $T$. pallidum, Nichols strain, and $T$. cuniculi were harvested from rabbit testicles, inoculated 2 to 4 weeks previously. $T$. carateum was obtained from fluid expressed from skin lesions in inoculated chimpanzees (Kuhn, Medina, Cohen, and Vegas, 1970). T. pertenue was obtained from skin lesions developing in macaques inoculated with a Received for publication March 17, 1971
Venezuelan strain of this organism provided by $\mathrm{Dr}$. Raphael Medina. Previously this strain had been cultivated i in Syrian hamsters. Fresh T.microdentium was obtained $\mathrm{G}$ from mouth washings.

All specimens were placed within pre-etched circles on alcohol-cleaned glass slides and allowed to dry in air. The slides were then fixed in acetone at room temperature for $10 \mathrm{~min}$., air dried, and stored at $-20^{\circ} \mathrm{C}$. (U.S. Department of Health. Education, and Welfare, 1969).

\section{STAINING TECHNIQUE}

The direst staining technique was performed by layering FITC-labelled anti- $T$. pallidum globulin of rabbit origin, previously absorbed with whole Reiter treponemes, VDRL lot 169 (Mothershed and Bullard, 1968), on to the antigen slides. The conjugate had been diluted $1: 40$ either in phosphate buffered saline (PBS) pH 7.2 (U.S. Department of Health, Education, and Welfare, 1969), containing 2 per cent. Tween 80 , or in $0.5 \mathrm{M}$ carbonate buffer pH 9.0 (Cherry, Goldman, and Carski, 1960), containing 2 per cent. Tween 80 . The conjugate was allowed to react at room temperature for $30 \mathrm{~min}$. in a moist chamber. After staining, the slides were rinsed twice either in PBS pH $7 \cdot 2$, or in $0.5 \mathrm{M}$ carbonate buffer $\mathrm{pH} 9.0$ for $5 \mathrm{~min}$. and then in distilled water for $5 \mathrm{~min}$. The slides were then blotted dry with bibulous paper and a small drop of mounting medium was applied. The mounting medium was prepared from nine parts glycerin to one part buffer. The buffers used for mounting were: PBS pH 7.2;0.01 M phosphate buffer pH 7.2;0.01 M carbonate buffer $\mathrm{pH} 9.0 ; 0.5 \mathrm{M}$ carbonate buffer $\mathrm{pH} 9.0$. Coverslips were then affixed.

In the indirect technique, the antigen slides were layered with $4+$ reactive human syphilitic control serum, VDRL lot 691, previously diluted with four parts VDRL FTA-ABS test sorbent, lot 694. This was allowed to react in a moist chamber for $30 \mathrm{~min}$. at $37^{\circ} \mathrm{C}$. The slides were then washed twice either in PBS pH $7 \cdot 2$, or in $0.5 \mathrm{M}$ carbonate buffer $\mathrm{pH} 9 \cdot 0$, for $5 \mathrm{~min}$. followed by one rinse in distilled water for $5 \mathrm{~min}$. The slides were blotted dry and overlayered with FITC-labelled anti-human globulin (VDRL lot $69169 \mathrm{C}$ ), rabbit origin. The conjugate had

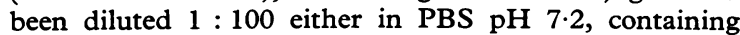
2 per cent. Tween 80 or in $0.5 \mathrm{M}$ carbonate buffer $\mathrm{pH}$ $9 \cdot 0$, containing 2 per cent. Tween 80 . After a second 30-min. incubation in a moist chamber at $37^{\circ} \mathrm{C}$., the slides were washed as before in one of the two buffers and in 
distilled water. They were blotted dry and mounted in the various glycerin-buffer mixtures described for the direct technique, and coverslips were affixed.

\section{MICROSCOPIC READING}

Observations were made at $540 \times$ magnification with a Leitz ultraviolet SM microscope, using a dark-field condenser and an HBO 200 mercury lamp. A BG-12 $3 \mathrm{~mm}$. thick exciting filter and OG-1 barrier filter were used. All specimens were read in a blind fashion by one observer, and graded as bright fluorescence, moderate fluorescence, weak fluorescence, or no fluorescence. All slides were prepared and read on three or four separate occasions.

\section{Results}

Table I summarizes the results obtained when lyophilized reconstituted $T$. pallidum (FTA-ABS test antigen), fresh $T$. pallidum Nichols strain, and washed and unwashed Reiter treponemes were stained by both the direct and indirect techniques, one of the two buffer systems being used throughout.

Both the FTA-ABS antigen and fresh Nichols strain $T$. pallidum stained brightly with the direct and indirect techniques when the PBS buffer system was used. The $\mathrm{pH} \mathrm{9.0} \mathrm{carbonate} \mathrm{buffer} \mathrm{severely}$ quenched the fluorescence of these organisms. The unwashed Reiter organisms stained weakly with the indirect method using PBS. This fluorescence was abolished when the organisms had been washed in saline. Varying the buffer used in the mounting media (0.01 M phosphate buffer $\mathrm{pH} 7.2$; PBS $\mathrm{pH} 7.2$; $0.01 \mathrm{M}$ carbonate buffer $\mathrm{pH} 9.0 ; 0.5 \mathrm{M}$ carbonate buffer $\mathrm{pH} 9.0$ ) caused no change in the fluorescence of the organisms.

Since Israel (1969) has used the $0.5 \mathrm{M}$ carbonate buffer $\mathrm{pH} 9.0$ in the indirect technique successfully, we decided to evaluate the action of the buffer more fully in our system. All combinations of the carbonate buffer and PBS were tested in the three steps of the indirect test as shown in Table II. Bright fluorescence was obtained when PBS was used throughout the technique or when the carbonate buffer was used only to wash the excess serumsorbent mixture from the antigen slides. Fluorescence was reduced severely when the carbonate buffer was used throughout. Moderate fluorescence remained with other combinations of the buffers.

TABLE I I Action of $0.5 \mathrm{M}$ carbonate buffer, $p H$ 9.0, and PBS, pH 7.2, upon indirect fluorescent antibody method using FTA-ABS test antigen

\begin{tabular}{|c|c|c|c|}
\hline $\begin{array}{l}\text { First wash } \\
\text { (to remove } \\
\text { serum and } \\
\text { sorbent) }\end{array}$ & $\begin{array}{l}\text { Diluent for } \\
\text { fluorescent } \\
\text { conjugate }\end{array}$ & $\begin{array}{l}\text { Second wash } \\
\text { (to remove } \\
\text { conjugate) }\end{array}$ & Fluorescence \\
\hline $\begin{array}{l}\text { PBS } \\
\text { Carbonate } \\
\text { PBS } \\
\text { PBS } \\
\text { Carbonate } \\
\text { Carbonate } \\
\text { PBS } \\
\text { Carbonate }\end{array}$ & $\begin{array}{l}\text { PBS } \\
\text { Carbonate } \\
\text { Carbonate } \\
\text { PBS } \\
\text { Carbonate } \\
\text { PBS } \\
\text { Carbonate } \\
\text { PBS }\end{array}$ & $\begin{array}{l}\text { PBS } \\
\text { Carbonate } \\
\text { Carbonate } \\
\text { Carbonate } \\
\text { PBS } \\
\text { PBS } \\
\text { PBS } \\
\text { Carbonate }\end{array}$ & $\begin{array}{l}\text { Bright } \\
\text { Weak } \\
\text { Moderate } \\
\text { Moderate } \\
\text { Moderate } \\
\text { Bright } \\
\text { Moderate } \\
\text { Moderate }\end{array}$ \\
\hline
\end{tabular}

The indirect and direct methods, using the PBS system, were then applied to a group of pathogenic treponemes, fresh $T$. microdentium, and washed Reiter treponemes (Table III). All pathogenic treponemes stained equally well with both techniques. Neither method stained fresh T. microdentium or washed Reiter treponemes.

\section{Discussion}

Various modifications of direct and indirect techniques have been used to detect treponemes in body fluids. Several workers originally used a direct staining technique with diluent buffered washes, and mounting media containing PBS pH $7 \cdot 2$ (Smith and Israel, 1968; Wells and Smith, 1967; Wilkinson, 1968). Goldman and Girard $(1967,1968)$ have used

T A B L E I Comparison of direct and indirect fluorescent antibody techniques with PBS, pH 7.2, or $0.5 \mathrm{M}$ carbonate, $p H 9 \cdot 0$, buffer systems

\begin{tabular}{|c|c|c|c|c|}
\hline \multirow[t]{2}{*}{ Organism } & \multicolumn{2}{|c|}{ Direct method } & \multicolumn{2}{|c|}{ Indirect method } \\
\hline & $\begin{array}{l}\text { PBS } \\
\text { pH } 7 \cdot 2\end{array}$ & $\begin{array}{l}\text { Carbonate } \\
\text { pH } 9 \cdot 0\end{array}$ & $\begin{array}{l}\text { PBS } \\
\text { pH } 7 \cdot 2\end{array}$ & $\begin{array}{l}\text { Carbonate } \\
\text { pH } 9.0\end{array}$ \\
\hline $\begin{array}{l}\text { Lyophilized, reconstituted } T \text {. pallidum, Nichols } \\
\text { strain (FTA-ABS test antigen) }\end{array}$ & Bright* & Weak & Bright & Weak \\
\hline Fresh $T$. pallidum, Nichols strain & Bright & Weak & Bright & Weak \\
\hline $\begin{array}{l}\text { Cultivated Reiter treponemes } \\
\text { Unwashed } \\
\text { Washed }\end{array}$ & $\begin{array}{l}\text { Negative } \\
\text { Negative }\end{array}$ & $\begin{array}{l}\text { Negative } \\
\text { Negative }\end{array}$ & $\begin{array}{l}\text { Weak } \\
\text { Negative }\end{array}$ & $\begin{array}{l}\text { Negative } \\
\text { Negative }\end{array}$ \\
\hline
\end{tabular}


I A B LE I I Comparison of direct and indirect fiuorescent antibody methods in staining of various organisms

PBS pH 7.2 was used throughout

\begin{tabular}{|c|c|c|}
\hline \multirow[t]{2}{*}{ Organism } & \multicolumn{2}{|c|}{ Intensity of fluorescence } \\
\hline & $\begin{array}{l}\text { Direct } \\
\text { method }\end{array}$ & $\begin{array}{l}\text { Indirect } \\
\text { method }\end{array}$ \\
\hline $\begin{array}{l}\text { Lyophilized, reconstituted } T \text {. } \\
\text { pallidum, Nichols strain (FTA-ABS } \\
\text { test antigen) }\end{array}$ & Bright & Bright \\
\hline Fresh $T$. pallidum, Nichols strain & Bright & Bright \\
\hline Fresh $T$. cuniculi & Bright & Bright \\
\hline Fresh $T$. pertenue & Bright & Bright \\
\hline Fresh $T$. carateum & Bright & Bright \\
\hline Fresh $T$. microdentium & Negative & Negative \\
\hline Cultivated Reiter treponemes, washed & Negative & Negative \\
\hline
\end{tabular}

both direct and indirect methods, while Golden employed only the latter (Golden, Watzke, Lindell, and McKee, 1968). More recently, some workers (Israel, 1969; Rice, Dunlop, Jones, Hare, King, Rodin, Mushin, and Wilkinson, 1970) have begun using the indirect method exclusively, and Israel (1969) has suggested using 0.5 M carbonate buffer $\mathrm{pH}$ 9.0. Reasons for preferring the indirect technique have included claims of increased intensity of fluorescence and ease of photographing the fluorescent organisms.

In the present study, both direct and indirect methods stained pathogenic treponemes equally well when the PBS system $\mathrm{pH} 7 \cdot 2$ was used. Good quality photographs of the fluorescing organisms were made with both black and white (ASA 400) and colour (ASA 500) film, using exposure times of 2 to $3 \mathrm{~min}$. Varying the $\mathrm{pH}$ and molarity of the buffer used in the glycerin-mounting medium had no effect on the observed fluorescence.

When both the direct and indirect techniques were used with the $0.5 \mathrm{M}$ carbonate buffer system $\mathrm{pH} 9 \cdot 0$, the fluorescence of pathogenic treponemes was severely diminished. Further evaluation showed that this effect could be traced to a direct action of the buffer primarily upon the FITC-globulin conjugate but also upon the $T$. pallidum-human syphilitic serum complex. Staining was consistently diminished to a moderate level when the buffer was used to dilute the FITC conjugate or to wash the excess conjugate from the slide. Since fluorescence remained bright when the carbonate buffer was used only to wash the excess human serum from the antigen slide, one might infer that the alkaline buffer quenched fluorescence primarily by causing dissociation of the FITC-antibody complex as has been suggested $\stackrel{\overline{\bar{S}}}{\vec{F}}$ by M. Goldman (1968). However, the greatest diminution of fluorescence occurred when the $\bar{F}$ buffer was used in all steps of the indirect technique, $\frac{\bar{p}}{\partial}$ indicating that the buffer also exerts some deleterious $\mathbb{\mathbb { Q }}$ effect upon the $T$. pallidum-human serum complex.

Since both direct and indirect fluorescent antibody techniques performed equally well in terms of treponeme morphology and brightness of fluorescence, no one method can be recommended by these criteria alone. However, when specificity for pathogenic treponemes is considered, some reservation must be expressed with the indirect method. Although the is present experiment, using one syphilitic serum, and of the work of J. N. Goldman (1968) demonstrated $O$

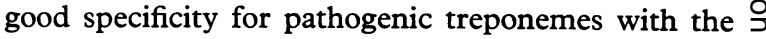
indirect method, other investigators (Wilkinson and Ferguson, 1968) have shown that, when strongly reactive human syphilitic serum is used in the indirect technique, sorbent may not remove all group anti-treponemal antibodies, and non-pathogenic $\vec{\omega}$ treponemes, such as Reiter, may fluoresce. (In $\searrow$ the present experiment, the weak fluorescence of unwashed Reiter treponemes, seen with the indirect technique, was probably caused by non-specific binding of human syphilitic serum to the rabbit serum in which the Reiter treponeme had been cultivated. The fluorescence disappeared when the organisms had been washed in saline before application to the glass slides.) Therefore, if the indirect technique is to be used, the investigator must either first evaluate the specificity of the sorbed syphilitic serum for pathogenic organisms, or examine fluorescing spiral forms for morphology and brightness alone, without regard for suspected pathogenicity.

\section{Summary}

In a comparative 'blind' study, both direct and indirect fluorescent antibody techniques stained $T$. pallidum and other pathogenic treponemes equally well. Severe decrease in fluorescence occurred when $N$ either method was used with a $\mathrm{pH} 9.0$ buffer system, as compared to good results obtained when $\mathrm{pH} \mathbf{7 \cdot 2}$ buffer was used. Although neither method stained selected non-pathogenic treponemes, r $\mathrm{r}$ servations are expressed when the indirect method is used without an evaluation of the specificity of the sorbed syphilitic serum.

\section{References}

Cherry, W. B., Goldman, M., and Carski, T. R. (1960) 'Fluorescent Antibody Techniques in the Diagnosis of Communicable Diseases'. Communicable Disease Center, U.S. Department of Health, Education and Welfare. Public Health Service 
Publication No. 729. U.S. Government Printing Office, Washington, D.C.

Edwards, E. A. (1962) Publ. Hlth Rep. (Wash.), 77, 427

Golden, B., WATZKe, R. C., LINDELL, S. S., and MCKeE, A. P. (1968) Arch. Ophthal. (Chicago), 80, 727

Goldman, J. N. (1968) In 'Clinical Methods in Uveitis: Fourth Sloan Symposium', ed. S. B. Aronson, C. N. Gamble, E. K. Goodner, and G. R. O'Connor, p. 172. Mosby, Saint Louis

and Girard, K. F. (1967) Arch. Ophthal. (Chicago), 78, 47

(1968) Ibid., 79, 716

Goldman, M. (1968) 'Fluorescent Antibody Methods', p. 178. Academic Press, New York

ISRAEL, C. W. (1969) In 'Spirochetes in Late Sero-negative Syphilis, Penicillin Notwithstanding', ed. J. Lawton Smith, p. 44. Thomas, Springfield, Ill.

Kunn, U. S. G., III, Medina, R., Cohen, P. G., and VeGAS, M. (1970) Brit. F. vener. Dis., 46, 311

MOTHERSHED, S. M., and BULLARD, J. C. (1968) Ibid., 44, 201

Rice, N. S. C., Dunlop, E. M. C., Jones, B. R., HaRe, M. J., KInG, A. J., Rodin, P., Mushin, A., and Wilkinson, A. E. (1970) Ibid., 46, 1

S.Mith, J. L., and Israel, C. W. (1968) Trans. Amer. Acad. Ophthal. Otolaryng., 72, 63

U.S. Department of Health, Education, and WeLFARE (1969) 'Manual of Tests for Syphilis 1969'. Public Health Service Publication No. 411. U.S.
Government Printing Office, Washington, D.C., 20402

Wells, J. A., and SMITH, J. L. (1967) Amer. F. Ophthal., 63, 410

WilkInson, A. E. (1968) Trans. ophthal Soc. U.K., 88, 251

, and Ferguson, H. G. (1968) Brit. F. vener. Dis., 44, 291

YoBS, A. R., Brown, L., and HunTER, E. F. (1964) Arch. Path., 77, 220

Comparaison des méthodes directe et indirecte de marquage à l'anticorps fluorescent pour Treponema pallidum

SOMMAIRE

Dans une étude comparative aveugle, les méthodes directe et indirecte utilisant l'anticorps fluorescent pour le marquage de $T$. pallidum et des autres tréponèmes pathogènes donnèrent les mêmes bons résultats. Une baisse marquée de la fluorescence survint, avec les deux méthodes, lorsqu'un système tampon à $\mathrm{pH} 9$ fut utilisé, alors que, par comparaison, de bons résultats furent obtenus avec un $\mathrm{pH}$ de 7,2. Quoiqu' aucune des méthodes ne put colorer des tréponèmes non pathogènes choisis, on fait des réserves sur la méthode indirecte si elle est utilisée sans avoir établi la spécificité de l'absorption utilisée pour le sérun syphilitique. 